
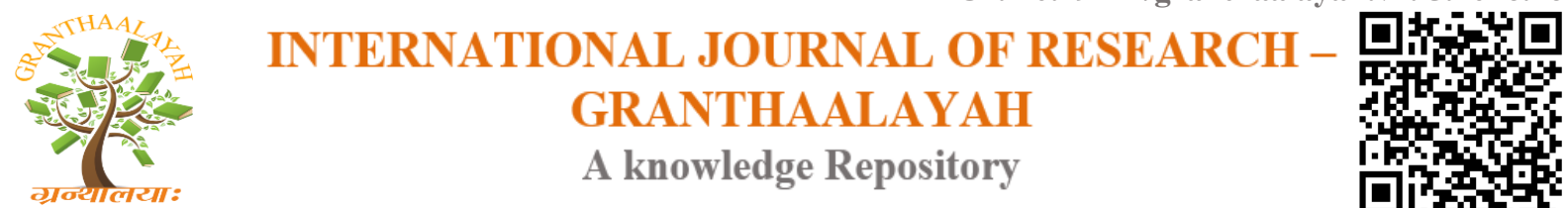

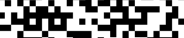
Irontipg alpristint

Management

\title{
AN ANALYSIS OF CORPORATE SOCIAL RESPONSIBILITY IN INDIA
}

\author{
Dr. Reena Shyam *1 \\ (M.B.A, M.Phil, Phd) \\ ${ }^{* 1}$ Associate Professor, Indian Academy School of Management Studies Hennur Cross, Hennur \\ Main Road , Kalyan nagar , Bangalore 43, INDIA
}

\begin{abstract}
Over the years Corporate Social Responsibility (CSR), a concept comparatively new to India, is rapidly picking up pace. CSR has become a fundamental business practice and has gained much attention from the management of large international companies. It facilitates the alignment of business operations with social values. CSR is deemed as a point of convergence of various initiatives aimed at ensuring socio-economic development of the community. Acknowledging the fact that mainstreaming CSR into businesses could be instrumental in delivering societal value, especially in a developing country like India, this paper specifically aims at providing an understanding of concept of CSR and analyses the development of CSR in India. It highlights the policies governing CSR in India and discusses the cases of CSR initiatives in Indian firms including SMEs role in CSR. There are several challenges facing CSR in India and the paper provides suggestions to overcome them and accelerate the CSR initiatives in India.
\end{abstract}

Keywords:

Corporate social responsibility, CSR initiatives, CSR Challenges.

Cite This Article: Dr. Reena Shyam, "AN ANALYSIS OF CORPORATE SOCIAL RESPONSIBILITY IN INDIA" International Journal of Research - Granthaalayah, Vol. 4, No. 5 (2016): 56-64.

\section{INTRODUCTION}

\section{AN ANALYSIS OF CORPORATE SOCIAL RESPONSIBILITY IN INDIA}

"A company should have in its DNA, a sense to work for the welfare of the community. CSR is an extension of individual sense of social responsibility. Active participation in CSR projects is important for a company"

- Ratan Tata

The concept of corporate social responsibility has gained prominence from all avenues. The present societal marketing concept of companies is constantly evolving and has given rise to a 
new concept-Corporate Social Responsibility. Many of the leading corporations across the world had realized the importance of being associated with socially relevant causes as a means of promoting their brands. It stems from the desire to do well and get self satisfaction in return as well as societal obligation of business. As an engine for social progress, CSR helps companies live up to their responsibilities as global citizens and local neighbors in a fast-changing world. ${ }^{1}$ For Indian businesses CSR can be a source of opportunity, innovation, and competitive advantage while at the same time providing with the opportunity to actively contribute to the sustainable development. Organizations in India have been quite sensible in taking up CSR initiatives and integrating them in their business processes. It has become progressively projected in the Indian corporate setting because organizations have recognized that besides growing their businesses, it is also important to shape responsible and supportable relationships with the community at large.

\section{OBJECTIVES}

1. To develop an understanding of concept of CSR

2. To analyze the development of CSR in India and its changing trends

3. To understand the policies governing CSR

4. To analyze the CSR initiatives in India including SMEs

4. To study the challenges faced by CSR in India

5. To provide suggestions for accelerating CSR initiatives

\section{RESEARCH METHODOLOGY}

The research paper is an attempt of exploratory research, based on the secondary data sourced from journals, magazines, articles, newspapers and media reports.

\section{CSR Defined}

Most definitions describe CSR as a concept whereby companies integrate social and environmental concerns in their business operations and in their interaction with their stakeholders on a voluntary basis. (CEC: Green Paper for Promoting a European Framework for Corporate Social Responsibility)

The World Business Council for Sustainable Development (WBCSD) defines CSR as "The continuing commitment by business to behave ethically and contribute to economic development while improving the quality of life of the work force and their families as well as of the local community and society at large".

Kotler and Lee define CSR as "Corporate social responsibility is a commitment to improve community well-being through discretionary, business practices and contribution of corporate resources. Corporate social initiatives are major activities undertaken by a corporation to support social causes and to fulfill commitments to corporate social responsibility"

Corporate social initiatives are major activities undertaken by a corporation to support social causes and to fulfill commitments to corporate social responsibility ${ }^{2}$. 
The conclusion would be that there is no unanimity on the definition of what constitutes Corporate Social Responsibility (CSR).However what could be taken into account CSR is generally used to describe business's efforts to achieve sustainable outcomes by committing to good business practices and standards.

\section{CSR ORIGIN AND DEVELOPMENT IN INDIA}

The concept of CSR has been imbibed in Indian society from the very beginning. Gandhi's philosophy of trusteeship is similar to CSR of the modern world; companies like TATA and BIRLA have been imbibing the case for social good in their operations for decades long before CSR become popular cause. The avid interest in community welfare among the Tata Group dates back to the 1860s when the company was founded by Jamshedji Tata. This explains why nearly two-thirds of the equity of Tata Sons, the Tata Group's promoter company, is held by philanthropic trusts, which have created a host of national institutions in science and technology, medical research, social studies and the performing arts.

Dr.Kurien's Amul-led Operation flood had pioneered inclusive growth through work with dairy farmers at grass-root level, changing lives, enhancing income, empowering women and at the same time reaping benefits to the business.

At Indian Oil, corporate social responsibility (CSR) has been the cornerstone of success right from inception in the year 1964. The Corporation's objectives in this key performance area are enshrined in its Mission statement: "...to help enrich the quality of life of the community and preserve ecological balance and heritage through a strong environment conscience." ${ }^{3}$

Before Corporate Social Responsibility found a place in corporate lexicon, it was already textured into the Birla Group's value systems. As early as the 1940s, the founderi G.D Birla espoused the trusteeship concept of management. Simply stated, this entails that the wealth that one generates and holds is to be held as in a trust for our multiple stakeholders. With regard to CSR, this means investing part of our profits beyond business, for the larger good of society ${ }^{4}$.

Over the years CSR has gained importance in India as companies are realizing the importance of investing in CSR for achieving benefits of creating share holder value, increased revenue base, strategic branding, operational efficiency, better access to capital, human and intellectual capital and lower business risk.CSR has emerged as an effective tool that synergizes the efforts of Corporate and the social sector towards sustainable growth and development of societal objectives at large.

\section{CHANGING TRENDS IN CSR : FROM CHARITY TO RESPONSIBILITY}

An insight into the history of CSR reveals that till 1990s it was solely dominated by the idea of philanthropy. Considering CSR as an act of philanthropy, businesses often restricted themselves to one time financial grant and did not commit their resources for such projects. Moreover, businesses never kept the stakeholder in mind while planning for such initiatives, thereby reducing the efficacy and efficiency of CSR initiatives. However, over the last few years, the concept of CSR has been changing. 
There has been an apparent transition from giving as an obligation or charity to giving as a strategy or responsibility ${ }^{5}$ Review of the case studies and work done on CSR by companies in India suggests that the CSR is slowly moving away from charity and dependence and starting to build on empowerment and partnership.

\section{MAKING A DIFFERENCE - CSR INITIATIVES IN INDIAN FIRMS}

Today, the corporate world has just started seeing the opportunity to help solve the problems CSR addresses. Private Sector has come out in favor of social responsibility and demonstrated their support for the Government's commitment to provide greater economic opportunities to the disadvantaged.

\section{POLICY INITIATIVES}

Realizing the role that can be played by corporate sector in addressing some of the glaring problems of a developing nation like India, ministry of corporate affairs (MCA) is expecting a fund flow of more than Rs 10,000 crore a year from private companies for social welfare initiatives as part of their CSR after Parliament clears the Companies Bill. Once the legislation is ratified by Parliament, India would become the first country to mandate CSR through a statutory provision. According to the proposal, it will be mandatory for private firms to earmark $2 \%$ of their average net profit for CSR initiatives. The government wants corporate houses to spend the sum in social sectors such as education and health rather than involving themselves in individual philanthropy ${ }^{6}$. MCA's draft voluntary guidelines on CSR are along global principles such as ethics and transparency, well-being of employees, human rights, health and safety, use of environment-friendly raw materials, following regulatory frameworks and larger engagement of stakeholders.

\section{SOME EXAMPLES OF INDIAN CORPORATIONS' CSR ACTIVITIES}

\section{WELSPUN ENERGY LTD (WEL)}

Socially responsible and ethical business practices are the defining tenets of Welspun's corporate philosophy. ASSOCHAM has identified Welspun Energy with its CSR Excellence Award 2012. Welspun Energy Ltd is part of the $\$ 3.5$ billion Welspun Group, which ranks amongst India's fastest emerging conglomerates with businesses in power generation, infrastructure, exploration and production of oil and natural gas, steel pipes and textiles

\section{CSR Programs}

By initiating programs like 'Training the Trainer', Enrolling children in Schools, 'Healthy Baby Competition' and Skill Development for Women, Welspun Energy has engaged with local communities to bring a positive change in their lives. Its social inclusion initiatives are beginning to show transformational results in Madhya Pradesh, Gujarat and Rajasthan.

Welspun Energy's leadership is also involved in various forums which are focused on sustainable growth on a global scale; these are - B20's Green Growth Action Alliance, World Economic Forum's (WEF's) Steering Committee on Sustainable Infrastructure \& Urban Development. 
HUL (RURAL MARKETING)

HUL's CSR philosophy is embedded in its commitment to all stakeholders, including consumers and employees, the environment, and the society the company operates in. The company depends on sustainable sources of raw materials, and is committed to minimizing the environmental impact, improving sustainability throughout the value chain.

$\begin{array}{ll}\begin{array}{l}\text { Relating CSR to Business Strategies } \\ \text { Product Development } \\ \text { Human Resource }\end{array} & \begin{array}{l}\text { Water conserving products } \\ \text { Hiring and investing in local talent } \\ \text { (merit-based through employment exchanges) }\end{array} \\ \begin{array}{l}\text { Manufacturing } \\ \text { Sourcing }\end{array} & \begin{array}{l}\text { Code Health Environment } \\ \text { Code of Business Practices }\end{array} \\ \text { (COBP) Compliance } \\ \text { Sales } & \begin{array}{l}\text { Shakti, cause marketing } \\ \text { Local enterprise development }\end{array} \\ \text { Profit apportionment } & \text { Community involvement initiatives }\end{array}$

\section{GUJARAT COOPERATIVE MILK MARKETING FEDERATION LTD (GCMMF)}

\section{CSR-orientation To Distributors \& Retailers}

The GCMMF has identified the distributors and retailers are its important link in its vendor supply chain. Through surveys the GCMMF found that $90 \%$ of the distributors do not get any opportunity of exposure to latest management practices. The GCMMF realised that it was a corporate social responsibility to strengthen the core business processes of its distributors so as to keep them in mainstream business and compete with those with formal training in management. The GCMMF has developed and trained all its distributors through Value-Mission-Strategy Workshops, competence building, Amul Yatra, Amul Quality Circle meetings, computerisation, and electronic commerce activities.

Competency Building Module of the GCMMF is meant to infuse professional selling skills by making the distributors and their salesmen aware of latest sales management tools and techniques; enhance their knowledge of products positioning and segmentation strategies for various products.

\section{CSR in SMEs}

The SMEs in India have grown phenomenally during last few years and have significant contribution in industrial output and exports from the country. They account for more than $80 \%$ of industrial enterprises and contribute to one of the highest shares of employment in the country especially in sectors like textiles, engineering, jute, auto ancillary, handicrafts etc. A thriving SME sector is crucial as an independent and as a supporting industry for large enterprises as well as MNCs.

Awareness about CSR is found to be very low amongst SMEs, however, many of them do carry out activities and implement CSR programmes without focusing on the term ' $\mathrm{CSR}$ " ${ }^{7}$ The overwhelming motivating factor for SMEs to engage in CSR is not external pressure but an internal drive to 'doing the right thing' or 'putting something back' or showing 'entrepreneurial 
spirit'. In the changing business scenario, it is important to work with and involve SMEs in promoting responsible business behavior that focuses on key stakeholders i.e. suppliers, customers, employees, community and the environment. According to a study by the European Commission in 2007 (CSR and SME Competitiveness SMEs' Good Practice), CSR can positively influence SMEs' competitiveness by Improved products and/or production processes, resulting in a better customer satisfaction and loyalty. Higher motivation and loyalty of employees, resulting in a higher creativity and innovativeness, Better publicity due to the award of prizes and/or enhanced word-of-the-mouth, better position at the labour market and better networking with business partners and authorities including better access to public funds due to a better company image. To remain competitive SMEs in India such as Elin Appliances Pvt. Ltd have realized the need to adapt to emerging changes in society and focus on CSR to gain crucial business advantage.

ELIN APPLIANCES PVT. LTD is an ISO 9001:2008 and ISO 14001:2004 certified company established in May, 2004 in Baddi, Himachal Pradesh has been awarded the CSR award in the category of SME Sector for manufacturing of Domestic Home Appliances for Philips Electronics Ltd CLS Division. Corporate by ASSOCHAM Social Responsibility (CSR) has always been an integral part of Elin's Corporate policy. The company firmly believes in improving the quality of life of the workforce, their family and local community.

\section{CSR Programs}

Elin Appliances Pvt. Ltd has pledged amounts equal to $2 \%$ of profit after tax (PAT) on a yearly basis for the Company's CSR initiatives, largely to benefit the socially and economical disadvantaged sections of society. The Company invests on the intellectual growth of its note employees by imparting training related to work and for social cause. As part of their employee relations, the company encourages active worker participation in the decision m.ing processes. Good performers are adequately awarded and recognized. Elin Appliances emphasizes on conservation of natural resources and environment protection. The company has initiated a "Go Green Initiative" which is a tree plantation drive and has vowed to plant and maintain 10,000 plants by year 2012. Besides, the company distributes tree saplings amongst employees and nearby villages during the environment week celebrations

\section{Challenges of CSR}

Although CSR has gained emphasis in India, there are several issues challenging its effectiveness and reach. A lack of proper understanding of the concept of CSR, non-availability of authentic data and specific information on the kinds of CSR activities, coverage, policy etc. are some of the various challenges facing CSR initiatives. Absence of training and undeveloped staff is additional problems for reduced CSR initiatives. A survey conducted by Times Group survey elicited responses from participating organisations about various challenges facing CSR initiatives in different parts of the country revealed.

- Lack of community participation in CSR activities: There is a lack of interest of the local community in participating and contributing to CSR activities of companies. This is largely attributable to the fact that there exists little or no knowledge about CSR within the local communities as no serious efforts have been made to spread awareness about CSR and instill confidence in the local communities about such initiatives. The situation 
is further aggravated by a lack of communication between the company and the community at the grassroots.

- Need to build local capacities: There is a need for capacity building of the local nongovernmental organizations as there is serious dearth of trained and efficient organizations that can effectively contribute to the ongoing CSR activities initiated by companies. This seriously compromises scaling up of CSR initiatives and subsequently limits the scope of such activities.

- Issues of transparency: Lack of transparency is one of the key issues brought forth by the survey. There is an expression by the companies that there exists lack of transparency on the part of the local implementing agencies as they do not make adequate efforts to disclose information on their programmes, audit issues, impact assessment and utilization of funds. This reported lack of transparency negatively impacts the process of trust building between companies and local communities, which is key to the success of any CSR initiative at the local level.

- Non-availability of well-organized non-governmental organizations: It is also reported that there is non-availability of well-organized nongovernmental organisations in remote and rural areas that can assess and identify real needs of the community and work along with companies to ensure successful implementation of CSR activities. This also builds the case for investing in local communities by way of building their capacities to undertake development projects at local levels.

- Visibility factor: The role of media in highlighting good cases of successful CSR initiatives is welcomed as it spreads good stories and sensitizes the local population about various ongoing CSR initiatives of companies. This apparent influence of gaining visibility and branding exercise often leads many non-governmental organizations to involve themselves in event-based programmes; in the process, they often miss out on meaningful grassroots interventions.

\section{SUGGESTIONS}

- In order to ensure that CSR is progressively contributing and benefiting, the following suggestions are given to make CSR initiatives more effective:

- It is found that there is a need for creation of awareness about CSR amongst the general public to make CSR initiatives more effective

- It is noted that partnerships between all stakeholders including the private sector, employees, local communities, the Government and society in general are either not effective or not effectively operational at the grassroots level in the CSR domain. It is recommended that appropriate steps be undertaken to address the issue of building effective bridges amongst all important stakeholders for the successful implementation of CSR initiatives. As a result, a long term and sustainable perspective on CSR activities should be built into the existing and future strategies of all stakeholders involved in CSR initiatives. 
- The role of SME and their contribution to CSR in India has to be emphasized upon to increase their contribution to CS initiatives. When compared to large corporations, SME play a limited role in CSR.SME have to be encouraged to posivitely contribute and reap the benefits of created by CSR

- Allocating finance for treating CSR as an investment from which returns are expected

- Monitoring CSR activities and liaising closely with implementation partners such as NGOs to ensure that initiatives really deliver the desired outcomes.

- A long term perspective by organisations, which encompasses their commitment to both internal and external stakeholders will be critical to the success of CSR and the ability of companies to deliver on the goals of their CSR strategy.

\section{CONCLUSION}

CSR is really about ensuring that the company can grow on a sustainable basis, while ensuring fairness to all stakeholders, CSR has come a long way in India. It has successfully interwoven business with social inclusion and environment sustainability. From responsive activities to sustainable initiatives, corporate have clearly exhibited their ability to make a significant difference in the society and improve the overall quality of life. In the current social situation in India, it is difficult for one single entity to bring about change, as the scale is enormous. Corporate have the expertise, strategic thinking, manpower and money to facilitate extensive social change. Effective partnerships between corporate, NGOs and the government will place India's social development on a faster track.

\section{REFERENCES}

[1] World business council for Sustainable Development (www.wbcsd.org/workprogram/business-role/previous-work/corporate-social-responsibility.aspx

[2] Kotler, Philip and Nancy Lee. Corporate Social Responsibility: Doing the most good for your business New Jersey: John Wiley \& Sons, Inc. 2005.

[3] 3 "CSR: A Cornerstone of our Enduring Success" Corporate Social Responsibility at India Oil http://iocl.com

[4] Corporate Social Responsibility Activities by the Aditya Birla Group http://www.adityabirla.com/social_projects/overview.html

[5] “Corporate Social Responsibility: Towards a Sustainable Future”, A white paper by KPMG \& Associated Chambers of Commerce and Industry of India(ASSOCHAM) in.kpmg.com/pdf/CSR_Whitepaper.pdf

[6] Mahendra Kumar Singh, Govt sees 10k crore flow/yr from CSR spend, Times of India, Feb 9, 2013,

[7] Heledd Jenkins, "Corporate social responsibility-engaging SMEs in the debate”, The centre for Business Relationships, Sustainability \& Society. http://www.brass.cf.ac.uk/uploads/CSRandSMEs.pdf

[8] http://www.ficci-sedf.org/CSR-Awards-Report2010.pdf

[9] Kotler, Philip and Lee, Nancy: Corporate Social Responsibility: Doing the most good for Your Company and your cause, John Wiley andSons, 2005.

[10] Brown K (2001), "Corporate Social Responsibility: Perceptions of Indian Business", in Mehra M (Ed.), Retrieved from www.csmworld.org/public/pdf/social_respons.pdf 
(Accessed February10th 2011) EU Green Paper (2001), Promoting a European Framework for Corporate Social Responsibility, Brussels, Commission of the European Communities, Retrieved from www.btplc.com/Societyandenvironment/ Reports/GreenpaperonCSR.pdf (Accessed February 10th 2011)

[11] Corporate Social Responsibility Practices in India The Times Foundation New Delhi

[12] Welspun Energy Bags ASSOCHAM Global CSR Excellence Award 2012 http://www.indiacsr.in

[13] Spend 2\% Profits on CSR, Pilot Tells Firms, 2013 http://www.indiacsr.in

[14] CSR COUNTRY BRIEF-India 2012 www.Innovation Norway

[15] Jadgish Ghulati, Indian Managers and their CSR Understanding: An Expert Panel Study

[16] CSR debate in India -From Philanthropy to Public-Private Partnership

[17] C. V. Baxi, Ajit Prasad, Corporate Social Responsibility: Concepts and Cases: The Indian Experience, Excel Books India, 2009

[18] Corporate Social Responsibility, The Amul Way, the Financial express 2004

[19] Emulate Amul-type CSR, World Bank Official Tells India Inc, Friday, 9th, 2012 http://www.indiacsr.in

[20] Corporate Social Responsibility (CSR) in India- a Report from Article 13 (www.article13.com)

[21] Arpan Banerjee, 'A New Dimension in Corporate Social Responsibility for Indian IT Firms', Asia Pacific Business and Technology report, 2009 